\title{
Quality Assessment of Omega-3 Supplements Available in the Brazilian Market
}

\author{
Marilia B. Galuch, ${ }^{a}$ Fabiana Carbonera, ${ }^{a}$ Thiago F. S. Magon, ${ }^{b}$ Roberta da Silveira, ${ }^{b}$ \\ Patrícia D. S. dos Santos, ${ }^{a}$ Jessica S. Pizzo, ${ }^{a}$ Oscar O. Santos ${ }^{b}$ and Jesuí V. Visentainer ${ }^{*}, a$ \\ ${ }^{a}$ Departamento de Química and ${ }^{b}$ Programa de Pós-Graduação em Ciência de Alimentos, \\ Universidade Estadual de Maringá (UEM), 87020-900 Maringá-PR, Brazil
}

\begin{abstract}
Omega-3 fish oil supplements are widely consumed as source of eicosapentaenoic (EPA) and docosahexaenoic (DHA) acids, presenting beneficial effects on human health. This study aimed to evaluate fifteen brands of omega-3 fish oil supplements available in Brazilian market in order to estimate the Brazilian reality regarding those supplements. Twelve fatty acids were quantified by gas chromatography with a flame ionization detector (GC-FID), and lipid profile were obtained via mass spectrometry fingerprinting using direct electrospray ionization mass spectrometry (ESI-MS) to assess the form in which fatty acids are present as well as the possible fraud existence. Among all analyzed samples, thirteen brands were revealed as EPA and DHA sources (90.2-440.3 and 77.8-302.3 $\mathrm{mg} \mathrm{g}^{-1}$ lipid, respectively) in triacylglycerols (TAG) or ethyl esters (EE) form. However, two brands were discovered with addition of large amounts of soybean oil, leading the final consumer to ingest this low-cost oil believing that they are consuming adequate doses of EPA and DHA.
\end{abstract}

Keywords: omega-3 supplements, adulteration, fish oil, soybean oil, lipid profile

\section{Introduction}

Long-chain n-3 polyunsaturated fatty acids (LCn-3PUFAs) are considered beneficial to human health. Clinical studies have demonstrated that their consumption, especially eicosapentaenoic acid (EPA, 20:5n-3) and docosahexaenoic acid (DHA, 22:6n-3), decreases the risk of chronic diseases. ${ }^{1}$ Furthermore, it is known that EPA and DHA can adjust cardiometabolic risk factors, ${ }^{2}$ have beneficial effects in the immune system, neurodegenerative disturbances, on some cancers, ${ }^{3}$ as well as being effective in reducing symptoms related to depression. ${ }^{4}$

EPA and DHA are almost exclusively found in marine products, ${ }^{5}$ fish oil being the main source of these compounds. ${ }^{3,6-8}$ However, high doses of omega-3 fatty acids are difficult to obtain exclusively from the $\operatorname{diet}^{9}$ and for this reason, there has been an increase in the consumption of fish oil as supplement. The consumption of marine-based supplements is advantageous since the amount of EPA and DHA ingestion can be controlled taking into account the label information, and is considered a safe and controlled manner to ingest them. ${ }^{10}$ However, the innumerous options available on the market make it difficult for consumers to

*e-mail: jesuiv@gmail.com choose a reliable option. Such supplements are vulnerable to adulteration due to the high price of fish oils; even labels could be adulterated so that they do not express the real amount of omega- 3 contained in the product. ${ }^{5}$ Plus, the correct dosage of EPA and DHA in omega-3 supplements is important, especially when their usage is warranted to treat adverse health conditions. ${ }^{11}$

Food authenticity and quality criteria are attracting the attention of consumers and enforcement agencies, since both are fundamental aspects for human health. The edible oils quality is commonly assessed by fatty acid composition, trace metals and lipid oxidation products quantifications. ${ }^{12}$ Besides that, it is important to detect food adulteration, mainly to protect the health of those who eat it, but also to evaluate if the high prices are consistent with the quality sought and acquired by the consumer, since they accept paying more for organic, $100 \%$ natural or products that have proven health benefits. However, considering technology advances, adulteration methods have been evolving so they are not easily detected. ${ }^{13}$

Taking into account the relevance of this subject, the aim of this study was to evaluate the quality of omega-3 supplements available in the Brazilian market. For that, the fatty acid composition of 15 brands ( 11 from Brazil, 3 from the United States and 1 from Germany) was determined 
by gas chromatography with a flame ionization detector (GC-FID; the most used method for such determinations in marine oils). ${ }^{1}$ Moreover, the lipid profiles of the supplements as well as of soybean oil were obtained via mass spectrometry (MS) fingerprinting using direct electrospray ionization mass spectrometry (ESI-MS), in order to monitor and detect possible marine oil adulteration with low-cost soybean oil, since ESI-MS direct analysis proved to be efficient in the characterization of complex mixtures through fingerprinting characteristic profiles. ${ }^{14}$

\section{Experimental}

\section{Samples}

Omega-3 supplements from 15 different brands (11 from Brazil, 3 from the United States and 1 from Germany) in capsule form were acquired in the local market of Maringá City (Paraná State, Brazil). Table 1 presents information provided by the manufacturer (on the label), such as country of origin, ingredients, amount of EPA and DHA ( $\left.\mathrm{mg} \mathrm{g}^{-1}\right)$, total omega-3 and fatty acid form. It is important to notice that sample 6 is the only one targeted at children and that it has soybean oil added to the formulation, specified on the label. Soybean oil was acquired in the local market of Maringá City (Paraná State, Brazil). Samples were kept in sealed tubes in a freezer at $-19{ }^{\circ} \mathrm{C}$.

Fatty acid composition by GC-FID

Quantification of fatty acids in the omega-3 supplement oils and soybean oil was carried out through fatty acid methyl esters (FAMEs) according to Hartman and $\mathrm{Lago}^{15}$ and modified by Maia and Rodriguez-Amaya. ${ }^{16}$

FAMEs were quantified on a Thermo gas chromatograph (Trace Ultra 3300) equipped with FID and a CP-7420 column (Select FAME, $100 \mathrm{~m}, 0.25 \mathrm{~mm}$ of internal diameter and $0.25 \mu \mathrm{m}$ of cyanopropyl). Gas flows were: carrier gas $\left(\mathrm{H}_{2}\right) 1.2 \mathrm{~mL} \mathrm{~min}^{-1}$; make-up gas $\left(\mathrm{N}_{2}\right) 30 \mathrm{~mL} \mathrm{~min}^{-1}$; detector flame: $35 \mathrm{~mL} \mathrm{~min}^{-1}$ for $\mathrm{H}_{2}$ and $350 \mathrm{~mL} \mathrm{~min}^{-1}$ for synthetic air. The injected sample volume was $2.0 \mu \mathrm{L}$, using a 1:80 sample split. Injector and detector temperatures were 200

Table 1. Specification from omega-3 supplement's label

\begin{tabular}{|c|c|c|c|c|c|}
\hline Omega-3 supplement & Country of origin & Ingredient & $\mathrm{EPA} /\left(\mathrm{mg} \mathrm{g}^{-1}\right)$ & DHA / $\left(\mathrm{mg} \mathrm{g}^{-1}\right)$ & Total omega-3 / $\left(\mathrm{mg} \mathrm{g}^{-1}\right)$ \\
\hline 1 & Brazil & fish oil & 200 & 100 & - \\
\hline 2 & Brazil & fish oil & 180 & 120 & - \\
\hline 3 & Brazil & fish oil & 171.4 & 114.3 & - \\
\hline 4 & United States & fish oil & b & $\mathrm{b}$ & - \\
\hline 5 & Brazil & fish oil & 200 & 100 & - \\
\hline $6^{\mathrm{a}}$ & Brazil & $\begin{array}{l}\text { fish oil, soybean lecithin, } \\
\text { beeswax, soybean oil, } \\
\text { xylitol, sucralose and fat } \\
\text { soluble cherry aroma }\end{array}$ & 200 & 200 & - \\
\hline 7 & United States & $\begin{array}{c}\text { anchovy, mackerel and } \\
\text { sardine oils; mixed } \\
\text { natural tocopherols }\end{array}$ & - & - & 300 \\
\hline 8 & Brazil & fish oil & 180 & 120 & - \\
\hline 9 & Brazil & fish oil & 180 & 120 & - \\
\hline 10 & Brazil & fish oil & 200 & 100 & - \\
\hline 11 & Brazil & fish oil & 166.7 & 116.7 & - \\
\hline 12 & United States & $\begin{array}{c}\text { anchovy, mackerel } \\
\text { and sardine oils; } \\
\text { mixed natural } \\
\text { tocopherols, acetylated } \\
\text { monoglycerides, } \\
\text { polysorbate } 80, \text { sodium } \\
\text { alginate, sorbic acid }\end{array}$ & 254.4-288 & $163.2-192$ & 480 \\
\hline 13 & Germany & $\begin{array}{c}\text { omega-3 fatty acids (fish } \\
\text { oil) }\end{array}$ & 470 & 330 & 1000 \\
\hline 14 & Brazil & fish oil & 600 & 400 & - \\
\hline 15 & Brazil & fish oil & 194 & 170 & - \\
\hline
\end{tabular}

antended for children; 'blabel only reports sum of EPA + DHA, being $300 \mathrm{mg} \mathrm{g}^{-1}$. EPA: eicosapentaenoic acid; DHA: docosahexaenoic acid. 
and $240{ }^{\circ} \mathrm{C}$, respectively. Chromatographic conditions employed involved a $30.00 \mathrm{~min}$ chromatographic run, wherein the column temperature schedule comprised the following steps: (i) $165{ }^{\circ} \mathrm{C}$ for $7.00 \mathrm{~min}$; (ii) heating ramp of $4{ }^{\circ} \mathrm{C} \mathrm{min}^{-1}$ to $185^{\circ} \mathrm{C}$; (iii) $185^{\circ} \mathrm{C}$ for $4.67 \mathrm{~min}$; (iv) heating ramp of $6{ }^{\circ} \mathrm{C} \mathrm{min}-1$ to $235{ }^{\circ} \mathrm{C}$; and (v) $235^{\circ} \mathrm{C}$ for $5.00 \mathrm{~min}$, as described by Carbonera et al. ${ }^{17}$ and Schneider et al. ${ }^{18}$ For FAMEs identification, retention times were compared with relative analytical standards (F.A.M.E. Mix, C4-C24, Sigma-Aldrich). For quantification, the internal standard tricosanoic acid methyl ester (SigmaAldrich, Darmstadt, Germany) was used as described by Visentainer. ${ }^{19}$ ChromQuest $^{\text {TM }} 5.0$ software was used to determine retention times and peak areas of FAMEs.

\section{Sample preparation for MS fingerprinting ESI(+)-MS}

In order to evaluate the lipid profiles, MS fingerprinting of the lipid material present in the omega- 3 supplements was carried out, comprising the mass/charge range between 100 and $1200(\mathrm{~m} / \mathrm{z})$. In addition, soybean oil was assessed to compare distinctive chemical profiles with those obtained for omega-3 supplements and to detect possible adulterations. The lipid materials were prepared based on Youzbachi et al.$^{20}$ with modifications: $50.0 \mu \mathrm{L}$ of oil was diluted in $950.0 \mu \mathrm{L}$ of chloroform (Synth, São Paulo, Brazil). $5.0 \mu \mathrm{L}$ of this solution was diluted with the addition of $1.0 \mathrm{~mL}$ of methanol/chloroform 9:1 (v/v) (HPLC grade, J.T.Baker ${ }^{\circledR}$, United States). In order to form ammonium adducts, $20.0 \mu \mathrm{L}$ of ammonium formate $0.10 \mathrm{~mol} \mathrm{~L}^{-1}$, prepared in methanol $(97 \%$, Sigma-Aldrich, Darmstadt, Germany), was added to the final solution.

ESI(+)-MS of oil in methanol favors ionization via $[\mathrm{M}+\mathrm{H}]^{+}$and $[\mathrm{M}+\mathrm{Na}]^{+} .{ }^{14}$ Therefore, ammonium formate was added to samples in order to form adducts and consequently prevailing the ionization via $\left[\mathrm{TAG}+\mathrm{NH}_{4}\right]^{+}$ so that the MS fingerprint reproducibility was not affected.

\section{ESI-MS instrumental conditions}

A triple quadrupole mass spectrometer (XEVO TQ-D, Waters, Massachusetts, United States) was used with a source of electrospray ionization (ESI). Properly prepared samples were introduced into the system by direct infusion, being ionized by electrospray operating in positive mode $(\operatorname{ESI}(+))$ according to the following conditions: source temperature $\left(150{ }^{\circ} \mathrm{C}\right)$, desolvation temperature $\left(200{ }^{\circ} \mathrm{C}\right)$, capillary voltage $(3.00 \mathrm{kV})$, cone voltage $(20.00 \mathrm{~V})$ and desolvation gas flow $\left(500 \mathrm{~L} \mathrm{~h}^{-1}\right)$. ESI-MS was focused on mass ranges of 100-1200 m/z. An analytical blank containing the used solvents was also infused for the subtraction of the obtained spectra for each sample.

\section{Statistical analysis}

Fatty acid composition data were submitted to analysis of variance (ANOVA) and means were compared by Tukey's test. The significance level used was 0.05 $(p<0.05)$. Principal component analysis (PCA) was performed to verify the relationships between the 15 omega-3 supplements available in the Brazilian market and soybean oil. Data were processed using Assistat software version 7.7. ${ }^{21}$

\section{Results and Discussion}

\section{Fatty acid composition}

Generally edible oil quality can be evaluated through fatty acid quantification. ${ }^{12}$ Therefore, 12 fatty acids were quantified in the lipid material present in capsules of omega-3 supplements (samples 1-15), and the results are presented in Table 2. Among them, samples 14 and 15 (both of Brazilian origin) were distinctive in composition compared to the other omega-3 supplements since they presented low levels of EPA and DHA, and high levels of linoleic acid (LA, 18:2n-6). Thus, since soybean oil has in its composition mainly LA, ${ }^{22}$ the same fatty acids were quantified in this vegetable oil in order to compare their contents with those found in samples 14 and 15; and the results are presented in Table 2.

Samples 12 and 13 presented the lowest levels of saturated fatty acids (SFA), and high levels of EPA and DHA, indicating concentration of omega- 3 fatty acids during the industrialization process. ${ }^{3}$ Besides that, sample 6 was the only one for which the manufacturer provided information that it contains soybean oil plus fish oil (as its major component). Consequently, for the results presentation, samples were separated into: samples 1-5 and 7-11, 6, 12-13, 14-15 and soybean oil.

As shown in Table 2, myristic acid (14:0) was found in the range of 57.5-74.1 $\mathrm{mg} \mathrm{g}^{-1}$ in samples 1-11, except for sample 6, in which the value found was $49.0 \mathrm{mg} \mathrm{g}^{-1} ; 13.6 \mathrm{mg} \mathrm{g}^{-1}$ was found in sample 12 and it was not detected (N.D.) in sample 13; 6.3 and $4.3 \mathrm{mg} \mathrm{g}^{-1}$ were found in samples 14 and 15 , respectively; it was N.D. in soybean oil. Palmitic acid $(\mathrm{P}, 16: 0)$ was found in the range of $139.6-159.6 \mathrm{mg} \mathrm{g}^{-1}$ in samples 1-11, except for sample 6 in which $135.7 \mathrm{mg} \mathrm{g}^{-1}$ was found; in sample 12, $38.2 \mathrm{mg} \mathrm{g}^{-1}$ was found and it was N.D. in sample 13; samples 14 and 15 presented 126.0 and $113.7 \mathrm{mg} \mathrm{g}^{-1}$, respectively; and $137.0 \mathrm{mg} \mathrm{g}^{-1}$ was found in 
Table 2. Fatty acid composition of omega-3 supplements and soybean oil

\begin{tabular}{|c|c|c|c|c|c|c|c|c|c|c|c|c|c|c|c|c|}
\hline \multirow{2}{*}{$\begin{array}{l}\text { Fatty } \\
\text { acids }\end{array}$} & \multicolumn{15}{|c|}{ Composition $^{\mathrm{a}}$ ( $\mathrm{mg} \mathrm{g}^{-1}$ lipid $)$} & \multirow{2}{*}{$\begin{array}{c}\text { Soybean } \\
\text { oil }\end{array}$} \\
\hline & 1 & 2 & 3 & 4 & 5 & 6 & 7 & 8 & 9 & 10 & 11 & 12 & 13 & 14 & 15 & \\
\hline & $2.7^{\mathrm{A}}$ & $\begin{array}{c}63.8 \pm \\
1.4^{\mathrm{B}}\end{array}$ & $\begin{array}{c}70.5 \pm \\
2.0^{\mathrm{A}}\end{array}$ & $\begin{array}{c}74.1 \pm \\
1.2^{\mathrm{A}}\end{array}$ & $\begin{array}{c}61.6 \pm \\
0.4^{\mathrm{BC}}\end{array}$ & $\begin{array}{c}49.0 \pm \\
1.1^{\mathrm{D}}\end{array}$ & $\begin{array}{c}57.5 \pm \\
0.8^{\mathrm{c}}\end{array}$ & $\begin{array}{c}72.3 \pm \\
2.5^{\mathrm{A}}\end{array}$ & $\begin{array}{c}71.8 \pm \\
2.8^{\mathrm{A}}\end{array}$ & $\begin{array}{c}71.6 \pm \\
1.8^{\mathrm{A}}\end{array}$ & $\begin{array}{c}61.9 \pm \\
0.3^{\mathrm{BC}}\end{array}$ & $\begin{array}{c}13.6 \pm \\
0.6^{\mathrm{E}}\end{array}$ & ${ }^{\mathrm{G}}$ & $\begin{array}{c}6.3 \pm \\
0.1^{\mathrm{F}}\end{array}$ & $\begin{array}{l}4.3 \pm \\
0.0^{\mathrm{FG}}\end{array}$ & ${ }^{\mathrm{G}}$ \\
\hline $6: 0$ & $\begin{array}{c}148.6 \pm \\
4.4^{\mathrm{B}}\end{array}$ & $\begin{array}{c}150.1 \pm \\
3.2^{\mathrm{B}}\end{array}$ & $\begin{array}{c}148.6 \pm \\
3.7^{\mathrm{B}}\end{array}$ & $\begin{array}{c}159.6 \pm \\
2.2^{\mathrm{A}}\end{array}$ & $\begin{array}{c}146.7 \pm \\
2.0^{\mathrm{BC}}\end{array}$ & $\begin{array}{c}135.7 \pm \\
2.5^{\mathrm{E}}\end{array}$ & $\begin{array}{c}159.6 \pm \\
2.0^{\mathrm{A}}\end{array}$ & $\begin{array}{c}145.5 \pm \\
5.1^{\mathrm{BC}}\end{array}$ & $\begin{array}{c}152.0 \pm \\
4.3^{\mathrm{AB}}\end{array}$ & $\begin{array}{c}139.6 \pm \\
2.6^{\mathrm{CDE}}\end{array}$ & $\begin{array}{c}145.4 \pm \\
0.4^{\mathrm{BCD}}\end{array}$ & $\begin{array}{c}38.2 \pm \\
1.7^{\mathrm{H}}\end{array}$ & I & $\begin{array}{c}126.0 \pm \\
2.4^{\mathrm{F}}\end{array}$ & $\begin{array}{c}113.7 \pm \\
0.9^{\mathrm{G}}\end{array}$ & $\begin{array}{c}137.0 \pm \\
0.7^{\mathrm{DE}}\end{array}$ \\
\hline$: 1 \mathrm{n}-7$ & $\begin{array}{c}85.7 \pm \\
2.6^{\mathrm{A}}\end{array}$ & $\begin{array}{l}74.9 \pm \\
1.7^{\mathrm{CD}}\end{array}$ & $\begin{array}{l}72.8 \pm \\
1.8^{\mathrm{CDE}}\end{array}$ & $\begin{array}{c}75.9^{ \pm} \\
1.3^{\mathrm{C}}\end{array}$ & $\begin{array}{l}72.5 \pm \\
1.1^{\mathrm{CDE}}\end{array}$ & $\begin{array}{c}57.1 \pm \\
1.1^{\mathrm{F}}\end{array}$ & $\begin{array}{c}56.6 \pm \\
0.7^{\mathrm{F}}\end{array}$ & $\begin{array}{l}83.8 \pm \\
2.6^{\mathrm{AB}}\end{array}$ & $\begin{array}{l}80.7 \pm \\
2.5^{\mathrm{B}}\end{array}$ & $\begin{array}{c}69.4 \pm \\
1.2^{\mathrm{E}}\end{array}$ & $\begin{array}{c}71.0 \pm \\
0.1^{\mathrm{DE}}\end{array}$ & $\begin{array}{c}23.9^{ \pm} \\
1.2^{\mathrm{G}}\end{array}$ & $1^{1}$ & $\begin{array}{c}9.6 \pm \\
0.1^{\mathrm{H}}\end{array}$ & $\begin{array}{c}6.4 \pm \\
0.0^{\mathrm{H}}\end{array}$ & N.D. ${ }^{I}$ \\
\hline 8:0 & $\begin{array}{c}28.2 \pm \\
0.6^{\mathrm{FG}}\end{array}$ & $\begin{array}{l}29.2 \pm \\
0.7^{\mathrm{EFG}}\end{array}$ & $\begin{array}{c}29.0 \pm \\
0.7^{\mathrm{FG}}\end{array}$ & $\begin{array}{l}30.3 \pm \\
0.5^{\mathrm{DEF}}\end{array}$ & $\begin{array}{c}28.4 \pm \\
0.5^{\mathrm{FG}}\end{array}$ & $\begin{array}{c}31.8 \pm \\
0.4^{\mathrm{DE}}\end{array}$ & $\begin{array}{c}32.6 \pm \\
0.3^{\mathrm{D}}\end{array}$ & $\begin{array}{c}27.9 \pm \\
0.8^{\mathrm{FG}}\end{array}$ & $\begin{array}{c}28.6 \pm \\
0.6^{\mathrm{FG}}\end{array}$ & $\begin{array}{c}27.8 \pm \\
0.5^{\mathrm{FG}}\end{array}$ & $\begin{array}{c}29.9 \pm \\
0.1^{\mathrm{EF}}\end{array}$ & $\begin{array}{c}26.7 \pm \\
1.2^{\mathrm{G}}\end{array}$ & $\begin{array}{c}0.1 \pm \\
0.0^{\mathrm{H}}\end{array}$ & $\begin{array}{c}42.2 \pm \\
0.6^{\mathrm{B}}\end{array}$ & $\begin{array}{c}38.9 \pm \\
0.0^{\mathrm{C}}\end{array}$ & $\begin{array}{c}50.9 \pm \\
2.6^{\mathrm{A}}\end{array}$ \\
\hline$: 1 \mathrm{n}-11$ & $\begin{array}{c}21.0 \pm \\
0.4^{\mathrm{BC}}\end{array}$ & $\begin{array}{c}23.7 \pm \\
0.2^{\mathrm{A}}\end{array}$ & $\begin{array}{c}21.8^{ \pm} \\
0.5^{\mathrm{B}}\end{array}$ & $\begin{array}{c}16.1 \pm \\
1.0^{\mathrm{DE}}\end{array}$ & $\begin{array}{c}15.7 \pm \\
0.2^{\mathrm{E}}\end{array}$ & $\begin{array}{c}17.3 \pm \\
0.4^{\mathrm{D}}\end{array}$ & N.D. ${ }^{G}$ & $\begin{array}{c}20.5 \pm \\
0.7^{\mathrm{BC}}\end{array}$ & $\begin{array}{c}21.8^{ \pm} \\
0.7^{\mathrm{B}}\end{array}$ & $\begin{array}{c}20.0^{ \pm} \\
0.8^{\mathrm{C}}\end{array}$ & $\begin{array}{c}14.8 \pm \\
0.0^{\mathrm{E}}\end{array}$ & $\begin{array}{c}6.2 \pm \\
0.4^{\mathrm{F}}\end{array}$ & $\begin{array}{c}0.4 \pm \\
0.0^{\mathrm{G}}\end{array}$ & N.D. ${ }^{G}$ & J.D. ${ }^{\mathrm{G}}$ &.$^{\mathrm{G}}$ \\
\hline $8: 1 n-9$ & $\begin{array}{c}66.8 \pm \\
2.0^{\mathrm{I}}\end{array}$ & $\begin{array}{c}76.4 \pm \\
3.0^{\mathrm{GH}}\end{array}$ & $\begin{array}{c}65.6 \pm \\
1.7^{\mathrm{IJ}}\end{array}$ & $\begin{array}{c}68.5 \pm \\
1.4^{1}\end{array}$ & $\begin{array}{c}93.5 \pm \\
1.9^{\mathrm{E}}\end{array}$ & $\begin{array}{c}86.0 \pm \\
1.6^{\mathrm{F}}\end{array}$ & $\begin{array}{c}145.7 \pm \\
1.3^{\mathrm{D}}\end{array}$ & $\begin{array}{l}66.0 \pm \\
2.2^{ \pm \mathrm{J}}\end{array}$ & $\begin{array}{l}81.2 \pm \\
2.1^{\mathrm{FG}}\end{array}$ & $\begin{array}{c}66.7 \pm \\
1.5^{\mathrm{IJ}}\end{array}$ & $\begin{array}{c}71.1 \pm \\
0.9^{\mathrm{HI}}\end{array}$ & $\begin{array}{l}59.9 \pm \\
2.5^{\mathrm{J}}\end{array}$ & $\begin{array}{c}0.9 \pm \\
0.1^{\mathrm{L}}\end{array}$ & $\begin{array}{c}227.4 \pm \\
3.5^{\mathrm{B}}\end{array}$ & $\begin{array}{c}250.2 \pm \\
0.3^{\mathrm{A}}\end{array}$ & $\begin{array}{c}198.7 \pm \\
4.9^{\mathrm{c}}\end{array}$ \\
\hline $8: 1 n-7$ & $\begin{array}{c}28.7 \pm \\
1.0^{\mathrm{AB}}\end{array}$ & $\begin{array}{c}26.1 \pm \\
1.6^{\mathrm{B}}\end{array}$ & $\begin{array}{c}26.5 \pm \\
0.8^{\mathrm{AB}}\end{array}$ & $\begin{array}{c}21.8^{ \pm} \\
0.9^{\mathrm{c}}\end{array}$ & $\begin{array}{c}26.7 \pm \\
0.7^{\mathrm{AB}}\end{array}$ & $\begin{array}{c}21.9^{ \pm} \\
0.4^{\mathrm{c}}\end{array}$ & $\begin{array}{c}19.5 \pm \\
0.1^{\mathrm{CD}}\end{array}$ & $\begin{array}{c}28.2 \pm \\
1.3^{\mathrm{AB}}\end{array}$ & $\begin{array}{c}28.0 \pm \\
1.0^{\mathrm{AB}}\end{array}$ & $\begin{array}{c}26.0 \pm \\
0.4^{\mathrm{B}}\end{array}$ & $\begin{array}{c}28.2 \pm \\
0.1^{\mathrm{AB}}\end{array}$ & $\begin{array}{c}29.3 \pm \\
1.1^{\mathrm{A}}\end{array}$ & $\begin{array}{c}0.3 \pm \\
0.0^{\mathrm{F}}\end{array}$ & $\begin{array}{c}17.4 \pm \\
0.3^{\mathrm{DE}}\end{array}$ & $\begin{array}{c}15.8 \pm \\
0.3^{\mathrm{E}}\end{array}$ & $\begin{array}{c}21.3^{ \pm} \\
2.0^{\mathrm{C}}\end{array}$ \\
\hline $\begin{array}{l}8: 2 n-6 \\
A\end{array}$ & $\begin{array}{c}10.2^{ \pm} \\
0.2^{\mathrm{E}}\end{array}$ & $\begin{array}{c}13.2 \pm \\
1.3^{\mathrm{DE}}\end{array}$ & $\begin{array}{c}13.3 \pm \\
0.2^{\mathrm{DE}}\end{array}$ & $\begin{array}{c}10.6 \pm \\
0.2^{\mathrm{DE}}\end{array}$ & $\begin{array}{c}12.0 \pm \\
0.4^{\mathrm{DE}}\end{array}$ & $\begin{array}{c}69.8 \pm \\
1.2^{\mathrm{C}}\end{array}$ & $0.2^{\mathrm{D}}$ & $0.3^{\mathrm{E}}$ & $0.3^{\mathrm{DE}}$ & $\begin{array}{c}10.5 \pm \\
0.1^{\mathrm{E}}\end{array}$ & $\begin{array}{c}10.6 \pm \\
0.1^{\mathrm{E}}\end{array}$ & $\begin{array}{c}9.0 \pm \\
0.3^{\mathrm{E}}\end{array}$ & $\begin{array}{c}0.8 \pm \\
0.1^{\mathrm{F}}\end{array}$ & $\begin{array}{c}432.1 \pm \\
6.9^{\mathrm{A}}\end{array}$ & $\begin{array}{c}428.7 \pm \\
0.8^{\mathrm{A}}\end{array}$ & $\begin{array}{c}414.5 \pm \\
7.7^{\mathrm{B}}\end{array}$ \\
\hline $\begin{array}{l}8: 3 n-3 \\
\text { LA }\end{array}$ & $\begin{array}{c}5.8 \pm \\
0.1^{\mathrm{E}}\end{array}$ & $\begin{array}{l}7.4 \pm \\
0.3^{\mathrm{DE}}\end{array}$ & $\begin{array}{l}9.6 \pm \\
0.3^{\mathrm{CDE}}\end{array}$ & $\begin{array}{l}7.3 \pm \\
0.2^{\mathrm{DE}}\end{array}$ & $\begin{array}{l}7.2 \pm \\
0.2^{\mathrm{DE}}\end{array}$ & $\begin{array}{c}12.2^{ \pm} \\
0.3^{\mathrm{C}}\end{array}$ & $\begin{array}{l}11.0 \pm \\
0.2^{\mathrm{CD}}\end{array}$ & $\begin{array}{c}6.1 \pm \\
0.1^{\mathrm{E}}\end{array}$ & $\begin{array}{l}7.1 \pm \\
0.1^{\mathrm{DE}}\end{array}$ & $\begin{array}{c}6.0 \pm \\
0.1^{\mathrm{E}}\end{array}$ & $\begin{array}{c}6.7 \pm \\
0.1^{\mathrm{E}}\end{array}$ & $\begin{array}{c}5.9 \pm \\
0.1^{\mathrm{E}}\end{array}$ & $\begin{array}{c}0.3 \pm \\
0.0^{\mathrm{F}}\end{array}$ & $\begin{array}{c}52.6 \pm \\
0.8^{\mathrm{B}}\end{array}$ & $\begin{array}{c}53.6 \pm \\
0.3^{\mathrm{B}}\end{array}$ & $\begin{array}{c}72.4 \pm \\
5.2^{\mathrm{A}}\end{array}$ \\
\hline $\begin{array}{l}0: 5 n-3 \\
\text { PA }\end{array}$ & $\begin{array}{c}162.1^{ \pm} \\
4.1^{\mathrm{C}}\end{array}$ & $\begin{array}{c}158.8 \pm \\
3.5^{\mathrm{C}}\end{array}$ & $\begin{array}{c}159.9 \pm \\
4.2^{\mathrm{C}}\end{array}$ & $\begin{array}{c}131.0 \pm \\
1.5^{\mathrm{D}}\end{array}$ & $\begin{array}{c}151.1 \pm \\
3.5^{\mathrm{c}}\end{array}$ & $\begin{array}{c}120.2 \pm \\
1.9^{\mathrm{D}}\end{array}$ & $\begin{array}{c}90.2 \pm \\
0.8^{\mathrm{E}}\end{array}$ & $\begin{array}{c}161.7 \pm \\
5.0^{\mathrm{C}}\end{array}$ & $\begin{array}{c}159.7 \pm \\
3.9^{\mathrm{C}}\end{array}$ & $\begin{array}{c}160.6 \pm \\
2.2^{\mathrm{C}}\end{array}$ & $\begin{array}{c}149.2 \pm \\
0.2^{\mathrm{C}}\end{array}$ & $\begin{array}{c}273.0^{ \pm} \\
11.2^{\mathrm{B}}\end{array}$ & $\begin{array}{c}440.3 \pm \\
15.7^{\mathrm{A}}\end{array}$ & $\begin{array}{c}2.6 \pm \\
0.1^{\mathrm{F}}\end{array}$ & $\begin{array}{c}3.4 \pm \\
0.3^{\mathrm{F}}\end{array}$ & N.D. ${ }^{F}$ \\
\hline $\begin{array}{l}2: 5 n-3 \\
P A\end{array}$ & $\begin{array}{c}19.4 \pm \\
1.0^{\mathrm{EF}}\end{array}$ & $\begin{array}{c}21.2 \pm \\
0.4^{\mathrm{DE}}\end{array}$ & $\begin{array}{c}21.3^{ \pm} \\
0.6^{\mathrm{D}}\end{array}$ & $\begin{array}{c}17.1 \pm \\
0.3^{\mathrm{GH}}\end{array}$ & $\begin{array}{c}18.6 \pm \\
0.3^{\mathrm{FJ}}\end{array}$ & $\begin{array}{c}15.9 \pm \\
0.2^{\mathrm{H}}\end{array}$ & $\begin{array}{c}12.9 \pm \\
0.2^{\mathrm{I}}\end{array}$ & $\begin{array}{l}19.6 \pm \\
0.4^{\mathrm{DEF}}\end{array}$ & $\begin{array}{l}19.8 \pm \\
0.3^{\mathrm{DEF}}\end{array}$ & $\begin{array}{c}23.2^{ \pm} \\
0.4^{\mathrm{C}}\end{array}$ & $\begin{array}{l}20.4 \pm \\
0.3^{\mathrm{DEF}}\end{array}$ & $\begin{array}{c}39.8^{ \pm} \\
1.7^{\mathrm{A}}\end{array}$ & $\begin{array}{c}33.2 \pm \\
1.0^{\mathrm{B}}\end{array}$ & + & $0^{\mathrm{J}}$ & N.D. \\
\hline $\begin{array}{l}2: 6 n-3 \\
\text { HA }\end{array}$ & $\begin{array}{c}106.1 \pm \\
2.9^{\mathrm{E}}\end{array}$ & $\begin{array}{c}99.1 \pm \\
2.7^{\mathrm{EF}}\end{array}$ & $\begin{array}{c}109.2 \pm \\
2.5^{\mathrm{DE}}\end{array}$ & $\begin{array}{c}118.8^{ \pm} \\
1.6^{\mathrm{D}}\end{array}$ & $\begin{array}{c}101.4 \pm \\
3.0^{\mathrm{E}}\end{array}$ & $\begin{array}{c}77.8 \pm \\
1.1^{\mathrm{H}}\end{array}$ & $\begin{array}{c}180.4 \pm \\
1.2^{\mathrm{B}}\end{array}$ & $\begin{array}{c}105.7 \pm \\
3.3^{\mathrm{E}}\end{array}$ & $\begin{array}{c}90.7 \pm \\
1.5^{\mathrm{FG}}\end{array}$ & $\begin{array}{c}84.0 \pm \\
1.3^{\mathrm{GH}}\end{array}$ & $\begin{array}{c}87.0 \pm \\
0.3^{\mathrm{GH}}\end{array}$ & $\begin{array}{c}162.6 \pm \\
7.3^{\mathrm{c}}\end{array}$ & $\begin{array}{c}302.3 \pm \\
9.3^{\mathrm{A}}\end{array}$ & $3=$ & & N.D. \\
\hline
\end{tabular}

a Results expressed as means \pm S.D. (standard deviation) of three replicates. Values with different uppercase letters in the same line are significantly different $(p<0.05)$ by Tukey's test. N.D.: not detected; LA: linoleic acid; ALA: $\alpha$-linolenic acid; EPA: eicosapentaenoic acid; DPA: docosapentaenoic acid; DHA: docosahexaenoic acid.

soybean oil. Meanwhile, stearic acid (S, 18:0) was found in the range of $27.8-32.6 \mathrm{mg} \mathrm{g}^{-1}$ in samples $1-11$, except for sample 6 in which $31.8 \mathrm{mg} \mathrm{g}^{-1}$ was found; 26.7 and $0.1 \mathrm{mg} \mathrm{g}^{-1}$ were found in samples 12 and 13, respectively; $42.2 \mathrm{mg} \mathrm{g}^{-1}$ was found in sample 14 and $38.9 \mathrm{mg} \mathrm{g}^{-1}$ in sample 15; and $50.9 \mathrm{mg} \mathrm{g}^{-1}$ was found in soybean oil.

The monounsaturated oleic acid $(\mathrm{O}, 18: 1 \mathrm{n}-9)$ was found in the range of 65.6-145.7 $\mathrm{mg} \mathrm{g}^{-1}$ in samples 1-11, except for sample 6 in which $86.0 \mathrm{mg} \mathrm{g}^{-1}$ was found; samples 12 and 13 presented 59.9 and $0.9 \mathrm{mg} \mathrm{g}^{-1}$, respectively; 227.4 and $250.2 \mathrm{mg} \mathrm{g}^{-1}$ were found in samples 14 and 15 , respectively; and $198.7 \mathrm{mg} \mathrm{g}^{-1}$ was found in soybean oil.

Linoleic acid (LA, 18:2n-6) was found in the range of 10.2-18.6 $\mathrm{mg} \mathrm{g}^{-1}$ in samples 1-11, except for sample 6 in which $69.8 \mathrm{mg} \mathrm{g}^{-1}$ was found; $9.0 \mathrm{mg} \mathrm{g}^{-1}$ was found in sample 12 and $0.8 \mathrm{mg} \mathrm{g}^{-1}$ in sample 13; 432.1 and $428.7 \mathrm{mg} \mathrm{g}^{-1}$ were found in samples 14 and 15 , respectively; and $414.5 \mathrm{mg} \mathrm{g}^{-1}$ was found in soybean oil, demonstrating the similarity between capsules 14 and 15 and soybean oil, as approximately $40 \%$ of its formulation is LA.

$\alpha$-Linolenic acid (ALA, 18:3n-3) was found in the range of 5.8-11.0 $\mathrm{mg} \mathrm{g}^{-1}$ in samples 1-11, except for sample 6 in which $12.2 \mathrm{mg} \mathrm{g}^{-1}$ was found; $5.9 \mathrm{mg} \mathrm{g}^{-1}$ was found in sample 12 and $0.3 \mathrm{mg} \mathrm{g}^{-1}$ in sample 13; 52.6 and $53.6 \mathrm{mg} \mathrm{g}^{-1}$ were found in samples 14 and 15 , respectively; and $72.4 \mathrm{mg} \mathrm{g}^{-1}$ was found in soybean oil. These results obtained for $\alpha$-linolenic acid also suggest that supplements 14 and 15 have been adulterated with the addition of soybean oil (a source of ALA), ${ }^{6,8}$ and consequently the amount of ALA in samples 14 and 15 was higher than that found in the other supplements. ALA is considered essential for humans,${ }^{23}$ as the conversion into EPA and DHA being one of its advantages. However, in the human body, such conversion has low efficiency. ${ }^{7,23}$

Regarding the EPA (20:5n-3), content between 90.2-162.1 $\mathrm{mg} \mathrm{g}^{-1}$ were found in samples 1-11, except for sample 6, in which $120.2 \mathrm{mg} \mathrm{g}^{-1}$ was found; 273.0 and $440.3 \mathrm{mg} \mathrm{g}^{-1}$ were found in samples 12 and 13, respectively; in samples 14 and 15, which presented high levels of LA, 2.6 and $3.4 \mathrm{mg} \mathrm{g}^{-1}$ were found, respectively; EPA was N.D. in soybean oil. It was also observed for docosapentaenoic acid (DPA, 22:5n-3) fatty acid, for which content was found in the range of 12.9-23.2 $\mathrm{mg} \mathrm{g}^{-1}$ in samples 1-11, except for sample 6 in which $15.9 \mathrm{mg} \mathrm{g}^{-1}$ was found; $39.8 \mathrm{mg} \mathrm{g}^{-1}$ was 
found in sample 12 and $33.2 \mathrm{mg} \mathrm{g}^{-1}$ in sample 13; 1.3 and $1.5 \mathrm{mg} \mathrm{g}^{-1}$ were found in samples 14 and 15 , respectively; DPA was N.D. in soybean oil. Lastly, DHA (22:6n-3) was found in the range of 84.0-180.4 $\mathrm{mg} \mathrm{g}^{-1}$ in samples 1-11, except for sample 6 , in which $77.8 \mathrm{mg} \mathrm{g}^{-1}$ was found; 162.6 and $302.3 \mathrm{mg} \mathrm{g}^{-1}$ were found in samples 12 and 13 , respectively; 4.3 and $4.1 \mathrm{mg} \mathrm{g}^{-1}$ was found in samples 14 and 15, respectively; and DHA was N.D. in soybean oil.

Allaire et al. ${ }^{2}$ reported that an increase of EPA + DHA in red blood cell membranes (O3I, omega-3 index) was observed with the consumption of supplements with high doses of DHA, compared with EPA, and O3I has already been associated with lower risk of coronary heart disease. It is important to note that, excluding sample 7, the analyzed samples (which were sources of EPA and DHA) were more concentrated in EPA than DHA.

\section{Principal component analysis (PCA)}

PCA was performed to contribute in the visualization and interpretation of the relationship between omega-3 supplements and soybean oil, using as variables the amount of LA, ALA, EPA and DHA ( $\left.\mathrm{mg} \mathrm{g}^{-1}\right)$. The biplot of PC1-PC2 (Figure 1) shows the samples separation (scores) according to the contribution of each variable (loadings) upon principal components. First principal component (PC1) explained $83.16 \%$ of the variance, while second component (PC2) explained 13.56\%. Therefore, PC1 and $\mathrm{PC} 2$ explained $96.72 \%$ of the total data variance. As observed in Figure 1, PCA clearly separated all 15 samples of omega-3 as well as soybean oil sample into 5 groups, represented by ellipses.

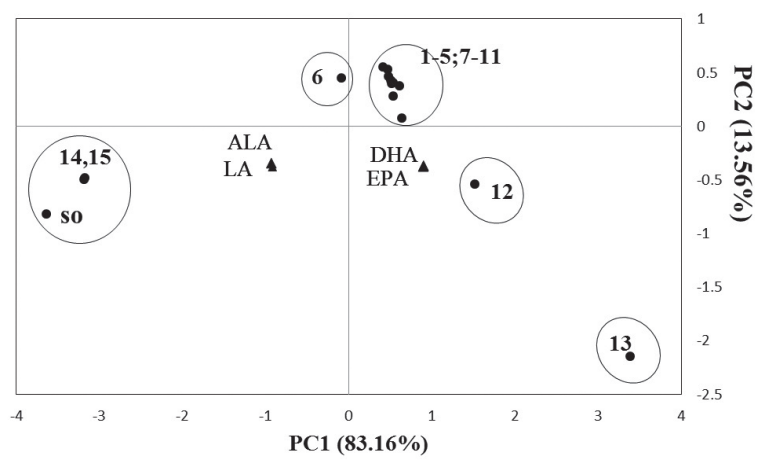

Figure 1. Biplot of PC1-PC2 of means of LA (linoleic acid, 18:2n-6), ALA ( $\alpha$-linolenic acid, 18:3n-3), EPA (eicosapentaenoic acid, 20:5n-3), and DHA (docosahexaenoic acid, 22:6n-3) contents, omega-3 supplements (samples 1-15) and soybean oil (SO).

Samples 1 to 11 were in a distinctive group, except for sample 6 (intended for children) which was also presented in a distinctive group as there is soybean oil in its constitution and, consequently, it presents a higher content of LA and ALA in comparison to samples 1 to 11 (1-5; 7-11).

Sample 12 has in its constitution similar amounts of LA and ALA when compared to samples 1-5 and 7-11. Nevertheless, it is part of a distinctive group due to its high amount of EPA. Sample 13, however, is part of another distinctive group because of in its constitution there are high amounts of EPA and DHA and lower amounts of LA and ALA in comparison to all other samples.

Moreover, samples 14 and 15 that presented high levels of LA and ALA, similar to soybean oil, and very low levels of EPA and DHA, were in a different group along with soybean oil, clearly illustrating the adulteration of these samples.

EPA/DHA ratio and sum of EPA + DHA

As EPA and DHA differ in their biological functions, ${ }^{24}$ these fatty acids perform differently in the organism. Consequently, some biological mechanisms require an adequate EPA/DHA ratio, ${ }^{3}$ and pharmaceutical applications require the ratio to be adequately controlled. ${ }^{7}$ Besides that, the control of EPA and DHA consumption is significant, especially for specific groups, such as people with coronary heart disease and those with elevated triglyceride levels. According to the American Heart Association, ${ }^{25}$ these specific groups of people must ingest a daily dose of $1 \mathrm{~g}$ and 2-4 $g$ of EPA + DHA, respectively.

Both the EPA/DHA ratio and the sum EPA + DHA $\left(\mathrm{mg} \mathrm{g}^{-1}\right)$ of samples are presented in Table 3. From the results it can be seen that in all 15 omega- 3 supplements, the EPA/DHA ratios for adulterated samples were 0.6 and 0.8 , and they ranged from 0.5 to 1.9 for other supplements. In addition, the sum of EPA + DHA from the lipid material present in the supplements ranged from 236.2 to $270.6 \mathrm{mg} \mathrm{g}^{-1}$ for samples 1-11, except for sample 6, which presented $198.1 \mathrm{mg} \mathrm{g}^{-1}$; in sample 12 it was $435.6 \mathrm{mg} \mathrm{g}^{-1}$ and in sample 13 it was $742.6 \mathrm{mg} \mathrm{g}^{-1} ; 6.9$ and $7.5 \mathrm{mg} \mathrm{g}^{-1}$ were found in samples 14 and 15 , respectively. Consequently, it was observed that samples 14 and 15, besides being adulterated, are not sources of EPA and DHA, as suggested by their labels.

\section{ESI-MS}

Fingerprint approaches are advantageous in studies where differentiation is involved, since such analysis allows the observation of the characteristic pattern of the samples. ${ }^{26}$ In this way, one group of samples can be compared with others, evaluating the differences between the profiles presented by them. 
Table 3. EPA/DHA ratio and the sum EPA + DHA of samples

\begin{tabular}{lcc}
\hline $\begin{array}{l}\text { Omega-3 supplements } \\
\text { sample }\end{array}$ & EPA/DHA ratio & $\begin{array}{c}\text { EPA + DHA / } \\
\left(\mathrm{mg} \mathrm{g}^{-1}\right)\end{array}$ \\
\hline 1 & $1.5 \pm 0.1$ & $268.3 \pm 5.0$ \\
2 & $1.6 \pm 0.1$ & $257.9 \pm 4.5$ \\
3 & $1.5 \pm 0.1$ & $269.0 \pm 4.9$ \\
4 & $1.1 \pm 0.0$ & $249.9 \pm 2.2$ \\
5 & $1.5 \pm 0.1$ & $252.5 \pm 4.4$ \\
6 & $1.6 \pm 0.0$ & $198.1 \pm 2.2$ \\
7 & $0.5 \pm 0.0$ & $270.6 \pm 1.5$ \\
8 & $1.5 \pm 0.1$ & $267.3 \pm 6.0$ \\
9 & $1.8 \pm 0.1$ & $250.4 \pm 4.1$ \\
10 & $1.9 \pm 0.0$ & $244.6 \pm 2.5$ \\
11 & $1.7 \pm 0.0$ & $236.2 \pm 0.4$ \\
12 & $1.7 \pm 0.1$ & $435.6 \pm 13.4$ \\
13 & $1.5 \pm 0.1$ & $742.6 \pm 18.3$ \\
14 & $0.6 \pm 0,0$ & $6.9 \pm 0.1$ \\
15 & $0.8 \pm 0.1$ & $7.5 \pm 0.3$ \\
\hline
\end{tabular}

EPA: eicosapentaenoic acid; DHA: docosahexaenoic acid.

Besides that, fatty acid quantification by GC-FID does not provide information on the form of these compounds in the lipid material of omega-3 supplements. Supplements based on fish oil are available as triacylglycerol (TAG) or fatty acid ethyl esters (EE) forms. ${ }^{3}$ However, EPA and DHA in TAG form are more bioavailable than the EE form. ${ }^{11,27}$ In this sense, knowing the EPA and DHA form in supplements is truly relevant. Nevertheless, such information is not always available on product labels. Among the analyzed brands, only samples 7 and 12 provided this information, been the fatty acids in TAG and EE forms, respectively.

Thus, MS fingerprinting using direct ESI(+)-MS was used to evaluate the lipid profile of oil present in omega-3 supplements in order to elucidate their fatty acid form (TAG or EE). It was also carried out with soybean oil, in order to compare its lipid profile with the profiles of capsules 14 and 15 , which were adulterated.

Figure 2 illustrates the spectra of samples $1-11$; it is possible to observe that these samples have characteristic lipid profiles and similarity as well. Furthermore, it was determined that the fatty acids in these supplements are in the TAG form, due to the most abundant region of ions, predominantly in $\mathrm{m} / \mathrm{z}, 800$ to 1500 . Zeng et al. ${ }^{26}$ found the same region of TAG when the marine oil profile was evaluated also through ionization $\left[\mathrm{TAG}+\mathrm{NH}_{4}\right]^{+}$. Fatty acids in the TAG form in omega-3 supplements are advantageous since their oxidative stability is higher (besides being more bioavailable). EE oxidizes more easily, producing compounds with adverse sensory characteristics. ${ }^{11}$

Figure 3 shows the spectra of samples 12 and 13; it can be seen that the fatty acids present in these supplements are in the EE form. Both capsules were concentrated in EPA and DHA in comparison to others, the major peaks at $m / z 331.41$ and 357.42 in the spectra referring to EE of EPA and DHA, respectively, as $[\mathrm{EE}+\mathrm{H}]^{+}$. In this case, there was no prevalence of ammonium adduct formation.

Figure 4 illustrates the TAG profile in the spectra of samples 14 and 15 as well as of the soybean oil. Samples 14 and 15 have characteristic and distinct TAG profiles
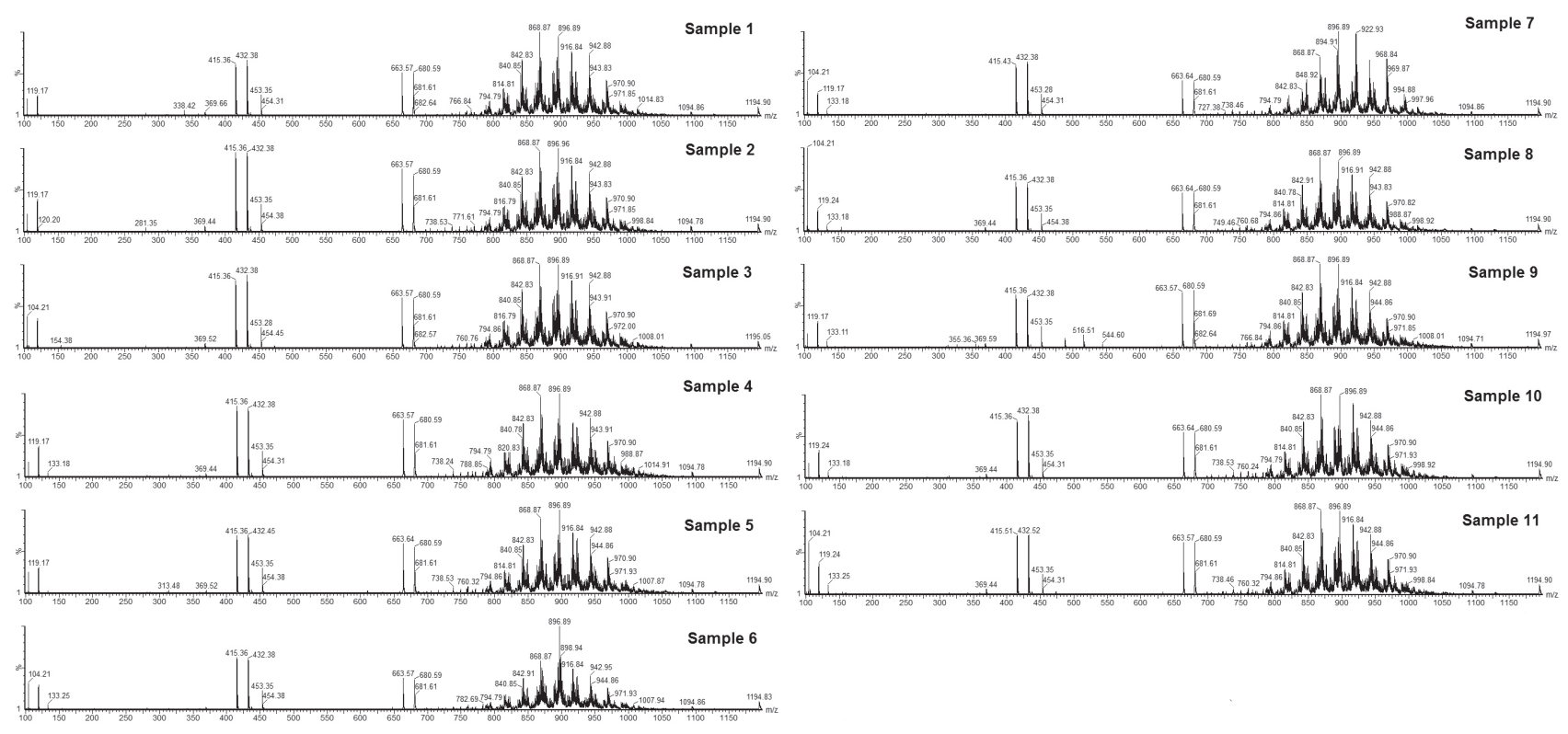

Figure 2. Lipid profile of samples 1-11, from ESI(+)-MS. 

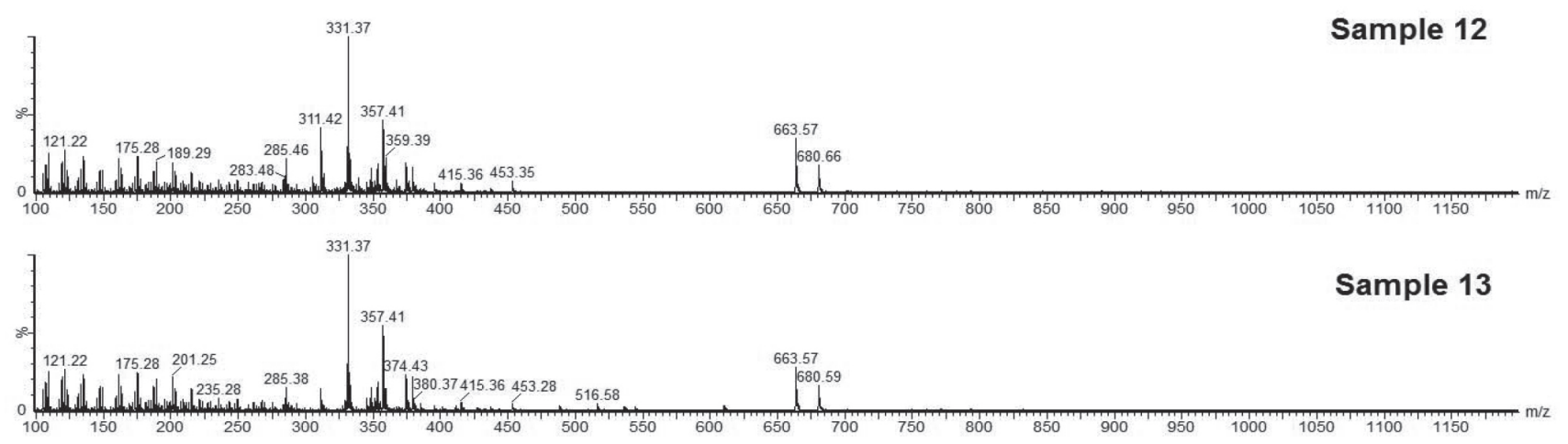

Figure 3. Lipid profile of samples 12 and 13 from ESI(+)-MS.
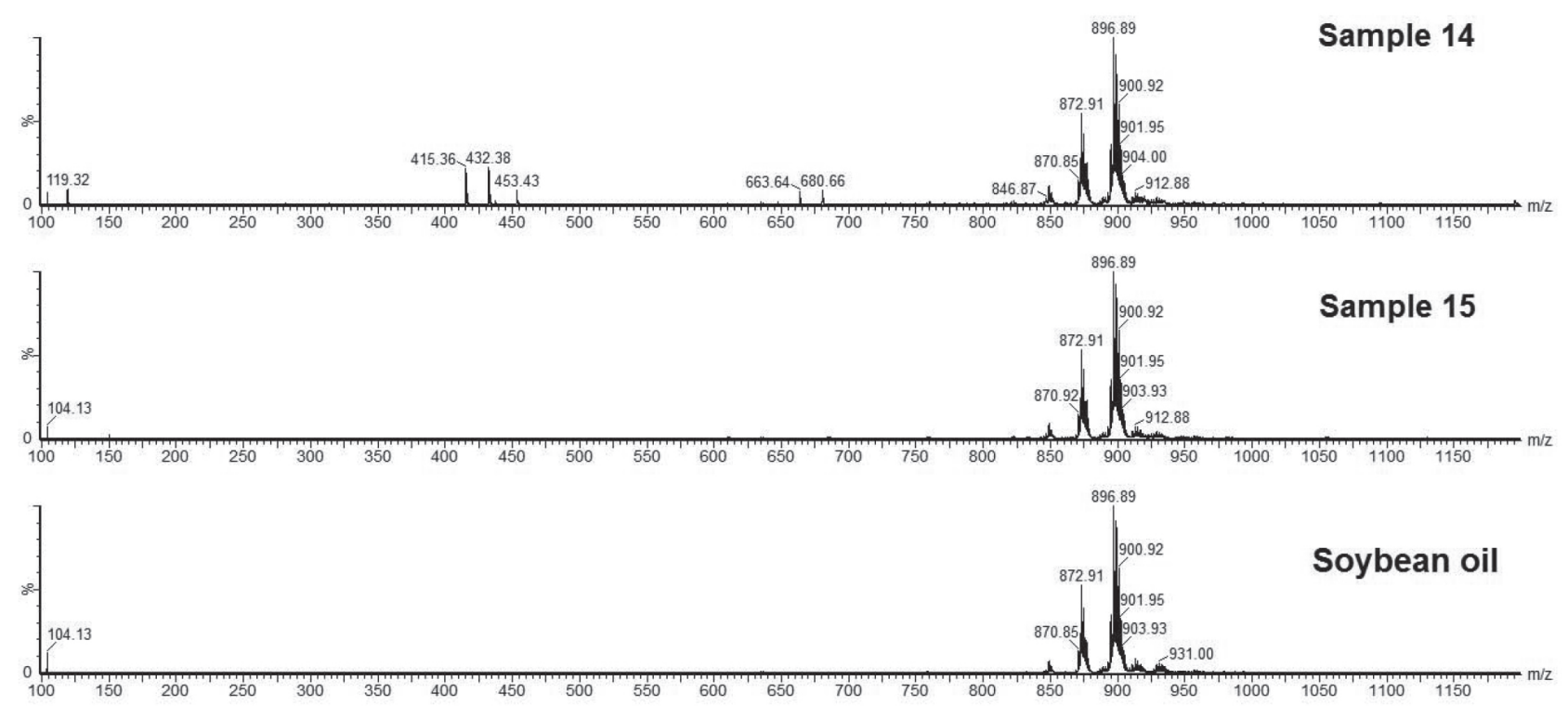

Figure 4. Lipid profile of samples 14, 15 and soybean oil, from ESI(+)-MS.

in comparison to the profiles presented by samples 1-11; however, they are similar to the soybean oil lipid profile. The region between $\mathrm{m} / \mathrm{z}, 850$ and 950 is the most abundant in $\left[\mathrm{TAG}+\mathrm{NH}_{4}\right]^{+}$for samples 14 and 15 and also for soybean oil. This region was also observed by Zeng et al. ${ }^{26}$ as the most abundant in $\left[\mathrm{TAG}+\mathrm{NH}_{4}\right]^{+}$ions when analyzing soybean oil lipid profile. Therefore, it has been shown that samples 14 and 15 are adulterated with large amounts of soybean oil, since a small addition of soybean oil would not abruptly modify the lipid profile, as demonstrated by the lipid profile of sample 6 , that has soybean oil in its composition (presented in Figure 2), or the fatty acid composition. It is concluded that samples 14 and 15 are almost exclusively soybean oil.

\section{Conclusions}

Through this study, in which 15 brands of omega-3 supplements available in the Brazilian market (11 produced in Brazil, 3 produced in the United States, and 1 produced in Germany) were evaluated, it was possible to determine the supplements' EPA and DHA sources as the TAG form (11 samples) or the EE form (2 samples). Furthermore, 2 brands of supplements adulterated with large amounts of soybean oil were observed; in Brazil, soybean oil is a cheap and abundant vegetable oil in comparison to fish oil. Thus, analytical methods that assess the quality of these supplements are truly important, since it could be a common practice as fish oil is relatively expensive.

\section{Supplementary Information}

Supplementary data with the spectra of each sample separately are available free of charge at http://jbcs.sbq.org.br as PDF file. 


\section{Acknowledgments}

The authors are grateful to CAPES and CNPq for the financial support and research grants.

\section{References}

1. Srigley, C. T.; Rader, J. I.; J. Agric. Food Chem. 2014, 62, 7268.

2. Allaire, J.; Harris, W. S.; Vors, C.; Charest, A.; Marin, J.; Jackson, K. H.; Tchernof, A.; Couture, P.; Lamarche, B.; Prostaglandins, Leukotrienes Essent. Fatty Acids 2017, 120, 8.

3. Bispo, P.; Batista, I.; Bernardino, R. J.; Bandarra, N. M.; Appl. Biochem. Biotechnol. 2014, 172, 1866.

4. Ginty, A. T.; Conklin, S. M.; Psychiatry Res. 2015, 229, 485.

5. Plans, M.; Wenstrup, M. J.; Rodriguez-Saona, L. E.; J. Am. Oil Chem. Soc. 2015, 92, 957.

6. Kris-Etherton, P. M.; Taylor, D. S.; Yu-poth, S.; Huth, P.; Moriarty, K.; Fishell, V.; Hargrove, R. L.; Zhao, G.; Etherton, T. D.; Am. J. Clin. Nutr. 2000, 71(suppl), 179S.

7. Kralovec, J. A.; Zhang, S.; Zhang, W.; Barrow, C. J.; Food Chem. 2012, 131, 639.

8. Gebauer, S. K.; Psota, T. L.; Harris, W. S.; Kris-Etherton, P. M.; Am. J. Clin. Nutr. 2006, 83(suppl), 1526S.

9. Hamilton, K.; Brooks, P.; Holmes, M.; Cunningham, J.; Russell, F. D.; Nutr. Diet. 2010, 67, 182.

10. Tatarczyk, T.; Engl, J.; Ciardi, C.; Laimer, M.; Kaser, S.; Salzmann, K.; Lenners, R.; Patsch, J. R.; Ebenbichler, C. F.; Wien. Klin. Wochenschr. 2007, 119, 417.

11. Ritter, J. C. S.; Budge, S. M.; Jovica, F.; J. Sci. Food Agric. 2013, 93, 1935.

12. Corazza, M. Z.; Tarley, C. R. T.; Microchem. J. 2016, 127, 145.

13. Ozen, B. F.; Weiss, I.; Mauer, L. J.; J. Agric. Food Chem. 2003, $51,5871$.
14. Cabral, E. C.; da Cruz, G. F.; Simas, R. C.; Sanvido, G. B.; Gonçalves, L. V.; Leal, R. V. P.; da Silva, R. C. F.; da Silva, J. C. T.; Barata, L. E. S.; da Cunha, V. S.; de França, L. F.; Daroda, R. J.; de Sá, G. F.; Eberlin, M. N.; Anal. Methods 2013, 5, 1385.

15. Hartman, L.; Lago, R. C.; Lab. Pract. 1973, 22, 474.

16. Maia, E. L.; Rodriguez-Amaya, D. B.; Rev. Inst. Adolfo Lutz 1993, 53, 27.

17. Carbonera, F.; Bonafe, E. G.; Martin, C. A.; Montanher, P. F.; Ribeiro, R. P.; Figueiredo, L. C.; Almeida, V. C.; Visentainer, J. V.; Food Chem. 2014, 148, 230.

18. Schneider, V. V. A.; Carbonera, F.; Montanher, P. F.; Lopes, A. P.; Matsushita, M.; Visentainer, J. V.; J. Am. Oil Chem. Soc. 2015, 92, 693.

19. Visentainer, J. V.; Quim. Nova 2012, 35, 274.

20. Youzbachi, N.; Trabelsi, H.; Elfalleh, W.; Khaldi, A.; Nasri, N.; Tlili, N.; Arab. J. Chem. 2015, DOI 10.1016/j. arabjc.2015.08.020.

21. Silva, F. A. S.; Azevedo, C. A. V.; Afr. J. Agric. Res. 2016, 11, 3733.

22. Rom, O.; Jeries, H.; Hayek, T.; Aviram, M.; BioFactors 2017, 43,100 .

23. Queen, K.; Nutr. Perspect.: J. Counc. Nutr. Am. Chiropr. Assoc. 2016, $39,9$.

24. Shang, T.; Liu, L.; Zhou, J.; Zhang, M.; Hu, Q.; Fang, M.; Wu, Y.; Yao, P.; Gong, Z.; Lipids Health Dis. 2017, 16, 65.

25. American Heart Association; https://healthyforgood.heart.org/ Eat-smart/Articles/Vitamin-Supplements-Hype-or-Help-forHealthy-Eating, accessed on August 24, 2017

26. Zeng, Y.; Araujo, P.; Grung, B.; Zhang, L.; Analyst 2011, 136, 1507.

27. Neubronner, J.; Schuchardt, J. P.; Kressel, G.; Merkel, M.; Von Schacky, C.; Hahn, A.; Eur. J. Clin. Nutr. 2010, 65, 247.

Submitted: August 25, 2017

Published online: October 5, 2017 